\title{
Applicability Analysis of Vegetation Condition and Dryness for Sand and Dust Storm (SDS) Risk Reduction in SDS Source and Receptor Region
}

\author{
Eunbeen Park ${ }^{1}{ }^{(\mathbb{D}}$, Jiwon Kim ${ }^{1}$, Cholho Song ${ }^{2}{ }^{\circledR}$, Hyun-Woo Jo ${ }^{1}$, Sujong Lee ${ }^{1}$, Sea Jin Kim ${ }^{1}{ }^{1}$, \\ Sugyeong Park ${ }^{3}$, Chul-Hee Lim ${ }^{2,4}$ and Woo-Kyun Lee ${ }^{1, *}$ \\ 1 Department of Environmental Science and Ecological Engineering, Korea University, Seoul 02841, Korea; \\ heyevvin@gmail.com (E.P.); keinesorge2@korea.ac.kr (J.K.); endeavor4a1@gmail.com (H.-W.J.); \\ leesj3610@gmail.com (S.L.); bluegulcy@gmail.com (S.J.K.) \\ 2 OJEong Resilience Institute (OJERI), Korea University, Seoul 02841, Korea; cholhosong@gmail.com (C.S.); \\ limpossible@korea.ac.kr (C.-H.L.) \\ 3 Department of Climatic Environment and Graduate School of Life and Environmental Sciences, \\ Korea University, Seoul 02841, Korea; synergyeong@gmail.com \\ 4 Institute of Life Science and Natural Resources, Korea University, Seoul 02841, Korea \\ * Correspondence: leewk@korea.ac.kr; Tel.: +82-02-3290-3016
}

Received: 25 July 2020; Accepted: 2 September 2020; Published: 4 September 2020

\begin{abstract}
Central Asian countries, which are included the Mid-Latitude Region (MLR), need to develop regional adaptive strategies for reducing Sand and Dust Storm (SDS)-induced negative damages based on adequate information and data. To overcome current limitation about data and assessment approaches in this region, the macroscale verified methodologies were required. Therefore, this study analyzed environmental conditions based on the SDS impacts and regional differences of SDS sources and receptors to support regional SDS adaptation plans. This study aims to identify environmental conditions based on the phased SDS impact and regional differences of SDS source and receptor to support regional adaptation plans in MLR. The Normalized Difference Vegetation Index (NDVI), Aridity Index (AI), and SDS frequency were calculated based on satellite images and observed meteorological data. The relationship among SDS frequency, vegetation, and dryness was determined by performing statistical analysis. In order to reflect phased SDS impact and regional differences, SDS frequency was classified into five classes, and representative study areas were selected by dividing source and receptor in Central Asia and East Asia. The spatial analysis was performed to characterize the effect of phased SDS impact and regional distribution differences pattern of NDVI and AI. The result revealed that vegetation condition was negatively correlated with the SDS frequency, while dryness and the SDS frequency were positively correlated. In particular, the range of dryness and vegetation was related to the SDS frequency class and regional difference based on spatial analysis. Overall, the Aral Sea and the Caspian Sea can be considered as an active source of SDS in Central Asia, and the regions were likely to expand into potential SDS risk areas compared to East Asia. This study presents the possibility of potential SDS risk area using continuously monitored vegetation and dryness index, and aids in decision-making which prioritizes vegetation restoration to prevent SDS damages with the macrolevel approach in the MLR perspective.
\end{abstract}

Keywords: Mid-Latitude Region (MLR); Normalized Difference Vegetation Index (NDVI); Aridity Index (AI); source and receptor; regional differences; Disaster Risk Reduction (DRR) 


\section{Introduction}

The Mid-Latitude Region (MLR) of northern hemisphere, which is roughly located between latitudes $30^{\circ}$ and $60^{\circ} \mathrm{N}$ and includes arid and semiarid region, contains the strongly affected area by environmental and climate variability [1]. The MLR overlaps the "global dust belt" extending from North Africa to Central and East Asia [2]. Therefore, all countries in MLR are suffered by frequent occurrence of Sand and Dust Storm (SDS) and land degradation driven by various climate, environmental, and socioeconomic factors [3-5]. In general, SDS are regarded as global disaster events accompanied by strong winds and sand lifted from desert areas. SDS originate mainly from desert areas (source areas) and pose substantial potential risks to areas near to source regions (receptor areas), as well as long-distance areas [6-8]. Since some countries in MLR of Asia continent have insufficient adaptive capacity to deal with SDS impact, people who live in MLR have suffered from various issues such as loss of agricultural productivity, human health including respiratory problems, and loss of their settlements such as infrastructure [9-12]. In this perspective, the MLR needs proper assessment of SDS impact and the adaptive pathway or strategies to address these problems because it is directly linked to building sustainable environmental society.

Although these problems are well known, considering all the influence factors in SDS analysis is difficult because of the variations of the climate condition, environmental conditions, and adaptation ability in each region. In the literature reviews, the Gobi Desert in Mongolia and Taklamakan Desert in North China are referred to as the largest sources of SDS that damage the surrounding areas. The SDS evaluations including East Asia have been conducted on a microscale (site or local scale) $[13,14]$ to a macroscale (regional to global scale) $[15,16]$, and microscale studies have focused mainly on the Gobi Desert and the Taklamakan Desert. Most of the studies focused on assessing the spatial-temporal distribution of SDS and atmospheric monitoring $[17,18]$. They used national observed SDS records or satellite images [19-23], and identified the relationship between surface features, such as land cover types, vegetation states, soil types, etc. and climate conditions, such as precipitation, land surface temperature, etc. [24-26]. The occurrence of SDS was concentrated in spring and early summer [25,26], mainly in Taklamakan Desert and Gobi Desert, and recently, it has been on the decline. Sun et al. [27] assessed spatial and temporal characteristics of SDS in China using the past 40 years of SDS records, and mentioned that Gobi Desert and Taklimakan Desert are major sources of East Asia. In SDS studies related to environmental variables, $\mathrm{Xu}$ et al. [28] investigated the relationship between characteristics of SDS and land surface characteristics (vegetation, soil texture, and etc.) and climate factors (temperature, wind speed, and precipitation). In addition, Sofue et al. [29] analyzed vegetation condition as a response to precipitation and seasonal SDS outbreak using both cross correlation and single regression analysis. They highlighted that vegetation and precipitation condition can affect the frequency of SDS outbreak. As various studies have been carried out around East Asia, where the world's largest deserts exist for centuries, research and policy actions such as afforestation and vegetation restoration have been carried out to reduce the occurrence and damage of SDS in East Asia [10]. Chinese and Mongolia government have implemented several projects such as "Green Belt", which is Mongolia-Republic of Korea joint forestation project for preventing SDS [30,31], "Grain for Green" [32,33], "Natural Forest Conservation program", and etc. Although the "Green Great Wall (GGW)" project showed that SDS frequency reduced as vegetation became dense in Northern China [34], not all researchers agree the effectualness of these vegetation projects. Fan et al. [35] and Middleton [36] emphasized that early green-up vegetation effectively suppresses the SDS occurrence. Therefore, proper comprehensive SDS assessment relies on observed SDS and developing the relationship with other environmental vegetation status and climate conditions.

The desiccation of the Caspian Sea and Aral Sea transformed themselves into new desert area, and active SDS sources, exposing the seafloor land in Central Asia as the river flows, had decreased [37-41]. The impacts of desertification and SDS have started to worsen since 1960 [42,43], and the SDS have been detrimental to vegetation and human [44,45]. The Central Asia-a newly emerged active SDS spot of global concern-China, and Mongolia have the similar environmental conditions. From environmental 
aspects, this refers to arid and semiarid zones, where average precipitation ranges from 0 to $226 \mathrm{~mm}$ and the temperature is in the range of $10-20^{\circ} \mathrm{C}$, with grasslands and bare lands constituting the dominant land covers [1]. Moreover, the existing data exhibit uncertainties due to accessibility and collection deficiencies [46,47], and only a few studies focus on SDS occurrence and simulation using atmospheric models [48]. Liu et al. [49] conducted large-scale desertification monitoring in five central Asian countries and noted that desertification in eastern Aral Sea and western Central Asia increased from 1995 to 2001. Indoitu et al. [39] investigated that there is significant SDS information gap in global literature and Central Asia literature due to numerous researches published in Russia before 1980s, although SDS observation began since 1930. In addition, the spatial-temporal distribution of SDS was assessed, Zolotokrylin et al. [50] concluded eastern Aral Sea and Turkmenistan were the main source of SDS. Despite their risky characteristics, SDS in Central Asia were not relatively predominant than other disasters in global scale literature reviews [8]. In particular, SDS studies and policy actions in Central Asia have not been received much support, despite the increasing number of reports on the rapid progress of desertification, vegetation loss, and SDS damages frequently occurring. However, UNCCD recently adopted the decision on addressing the negative impact of SDS (COP. 13 in 2007 and COP. 14 in 2019) and have collaborated with Central Asia partners to develop SDS risk reduction plans, and this project started from January 2020. Moreover, according to UNEP et al. [10], adapting SDS in source and impact area requires science-based regional to global cooperation and partnership, and it is linked to implementation of 2015 Sendai Framework for Disaster Risk Reduction (DRR) [8,51]. In the light of the situation, this study suggests the need to establish basic collaborative information by understanding the relationship between environment and climate factors with SDS on a macroscale, including Central Asia.

In order to propose an adaptive strategy for reducing SDS damages and environmental sustainability, it is essential that basic research should be accompanied by accurate environmental factors with proper observed SDS data. After that, we can figure out which strategies is appropriate to reduce and prevent SDS impacts. Therefore, harmonization of macroscale assessment using available geographic information and microscale adaptation measures would be necessary in MLR where is suffered by the SDS. In the current stage, few studies discussed comprehensive SDS assessment on a macroscale in the environmental aspect, although SDS have no political boundaries, and their effects are continuous [3]. In addition, there are many uncertainties regarding the precise definition and interpretation of SDS, raising several controversies [3,5,52]. Despite these controversies, there is an urgent necessity to analyze the relationship between SDS and vegetation condition and climate factors that can be improved by human action.

Hence, this study aims to identify the relationship between general land surface characteristics and SDS over the entire MLR region, including Central Asia, which lacks relevant information and data despite being an active source and receptor, by SDS classification and region distinction. Moreover, we discuss possible supporting actions necessary for enhancing the adaptive capacity to SDS in the Central Asia region.

\section{Materials and Methods}

\subsection{Study Area}

The study area lies in northern MLR where heavy land degradation and ecological transitions have occurred [1,4]. To identify the overall trend of environmental characteristics, we selected the focusing zone, where the land cover has transitioned from forest to bare land, from where the desert starts (Mongolia) to the end of the bare land (Caspian Sea).

The study area is located between the latitudes of $36.46^{\circ}$ and $60.15^{\circ} \mathrm{N}$ and longitudes of $46.58^{\circ}$ and $119.88^{\circ} \mathrm{E}$ and includes Central Asia, North China, and Mongolia. Approximately, $48.3 \%$ of the total area consists of bare lands, grasslands, and regions with sparse vegetation. In this region, forests and croplands are predominant in the northern part, while bare land, shrubland, and rare grassland 
are specific to the southern part. The global meteorological stations located in the MLR are shown in Figure 1.
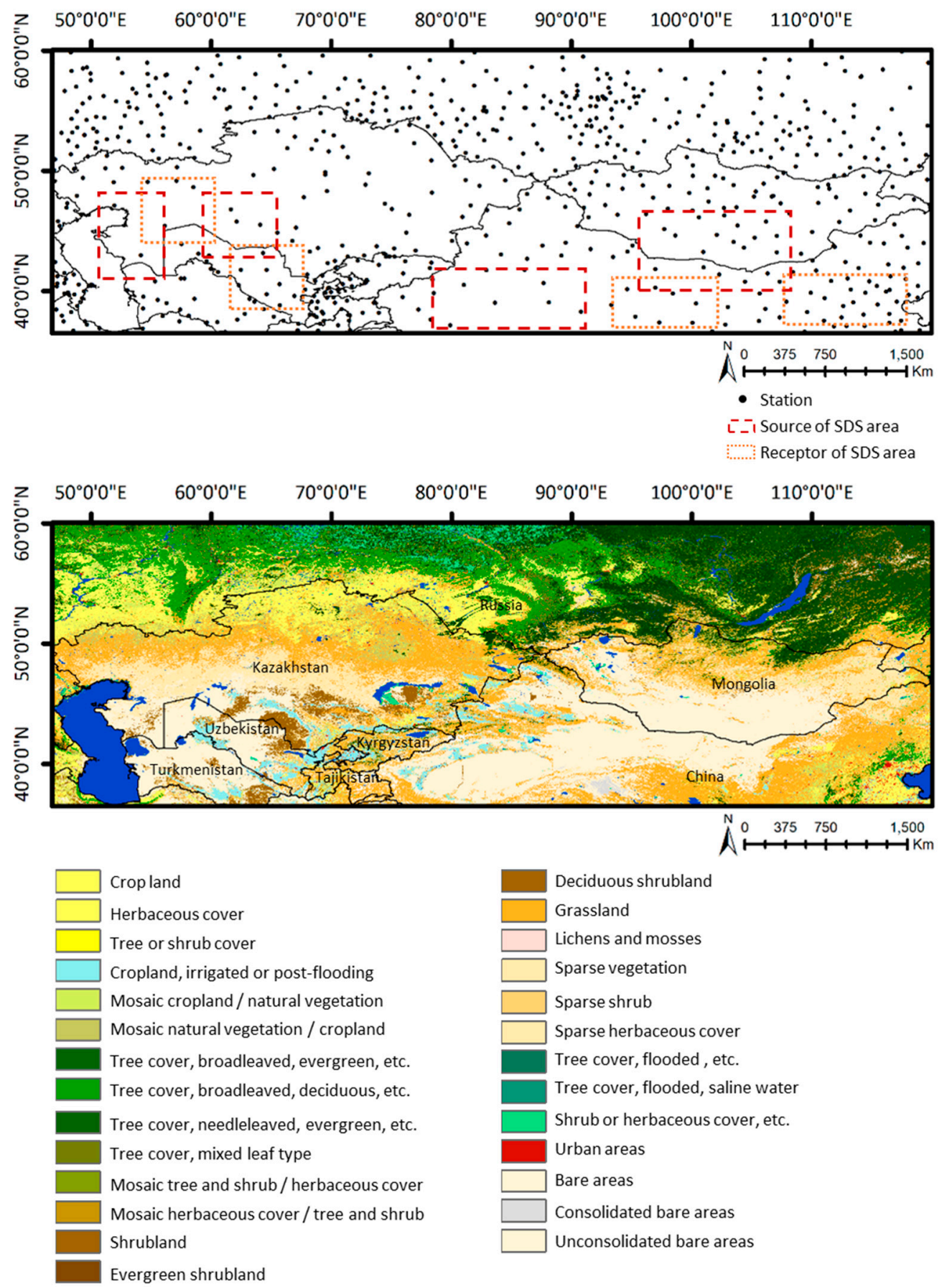

Figure 1. Meteorological stations and land cover map of study area.

In this study, the entire region was largely divided into East Asia and Central Asian regions, and four representative sources of SDS area and their surrounding receptor of SDS areas were selected from each region in consideration of the environment and topography (Table 1). The Karakum and Kyzylkum Desert around the Caspian and Aral Sea are the main SDS occurrence and damaged areas in Central Asia [38,53], and the Gobi Desert and Taklamakan Desert are the main SDS occurrence and damage regions in East Asia [50]. Middleton and Kang [3] assessed the global distribution of the SDS impact by grouping the SDS source areas with its corresponding receptors into categories. Thus, we 
divided each East Asia and Central Asia into main source areas, which are mainly deserts and bare lands and the surrounding receptor areas.

Table 1. Selected sand and dust storm (SDS) sources and SDS receptors in Central Asia and East Asia.

\begin{tabular}{cccc}
\hline \multicolumn{2}{c}{ Selected Area } & Longitude & Latitude \\
\hline Caspian Sea & SDS source & $50.302-56.683$ & $39.712-46.029$ \\
in Central Asia & SDS receptor & $55.618-60.935$ & $44.778-50.157$ \\
\hline Aral Sea & SDS source & $59.872-66.906$ & $42.089-47.906$ \\
in Central Asia & SDS receptor & $63.75-70.693$ & $36.772-42.401$ \\
\hline Taklamakan Desert in & SDS source & $76.322-90.083$ & $36.459-40.525$ \\
East Asia & SDS receptor & $92.022-98.027$ & $36.647-40.15$ \\
\hline Gobi Desert & SDS source & $96.025-106.283$ & $39.211-45.341$ \\
in East Asia & SDS receptor & $108.598-118.355$ & $36.897-40.275$ \\
\hline
\end{tabular}

\subsection{Data}

\subsubsection{SDS Meteorological Dataset}

The global weather observation dataset is part of the Met Office Integrated Data Archive System (MIDAS) database collection of the National Centre for Atmospheric Science (NCAS), British Atmospheric Data Centre [54]. The surface SYNOPtic observations (SYNOP) reports cover $24 \mathrm{~h}$ per day, and weather activity data were collected at 3-h intervals (00:00 a.m., 3:00 a.m., 6:00 a.m., 9:00 a.m., 12:00 a.m., 3:00 p.m., 6:00 p.m., 9:00 p.m.) from 706 meteorological stations (Figure 1). Each activity dataset includes horizontal visibility, wind speed, World Meteorological Organization (WMO) weather code, latitude, and longitude.

\subsubsection{AVHRR GIMMS NDVI3g}

NDVI is an effective indicator of land surface features and vegetation changes calculated from the difference between the reflectance of visible red $(0.58-0.68 \mu \mathrm{m})$ and near infrared $(0.725-1.100$ $\mu \mathrm{m})$ bands [55] (1). NDVI values range from -1.0 to +1.0 . High NDVI values correspond to dense vegetation, and low NDVI values show barren to sparse vegetation.

$$
\mathrm{NDVI}=\left(\mathrm{P}_{\text {nir }}-\mathrm{P}_{\text {red }}\right) /\left(\mathrm{P}_{\text {nir }}+\mathrm{P}_{\text {red }}\right)
$$

In particular, the Advanced Very High-Resolution Radiometer (AVHRR) NDVI is suitable for application at a continental and global scale and, therefore, also suitable for assessing the MLR [56-58]. For this study, the NDVI dataset (GIMMS NDVI3g) was obtained from the AVHRR satellite records of the United States National Oceanic and Atmospheric Administration (NOAA) and was generated as a 30-year time-series data (1984-2013). The NDVI dataset was recalculated as annual mean by taking pixels with a resolution of $0.083^{\circ}$ for 30 years.

\subsubsection{Aridity Index}

Aridity has been known to be computed in various ways, and AI is widely used to define arid regions based on climate data $[14,59,60]$. Thornthwaite AI [61] is calculated by the ratio between precipitation and potential evapotranspiration (2).

$$
\mathrm{AI}=\text { Precipitation }(\mathrm{mm} / \mathrm{year}) / \text { Potential Evapotranspiration (mm/year) }
$$

In this study, remote sensing-based yearly precipitation and potential evapotranspiration from 1984 to 2013 were obtained from the Climatologies at High resolution for the Earth's Land Surface Areas (CHELSA) data portal system. The AI was generated with the R package "Environmental Raster 
for Ecological Modeling (ENVIREM)" and modified, in the range of 0 to 100, with higher values indicating drier conditions. The AI dataset was calculated as annual means by taking pixels with a resolution of $0.083^{\circ}$ for 30 years.

\subsection{Data Processing and Analysis}

Data processing was conducted in three parts, using SDS observation data, NDVI, and AI. The statistical analysis was performed based on each indicator, and the spatial analysis was performed based on SDS classes and representative regions (Figure 2).

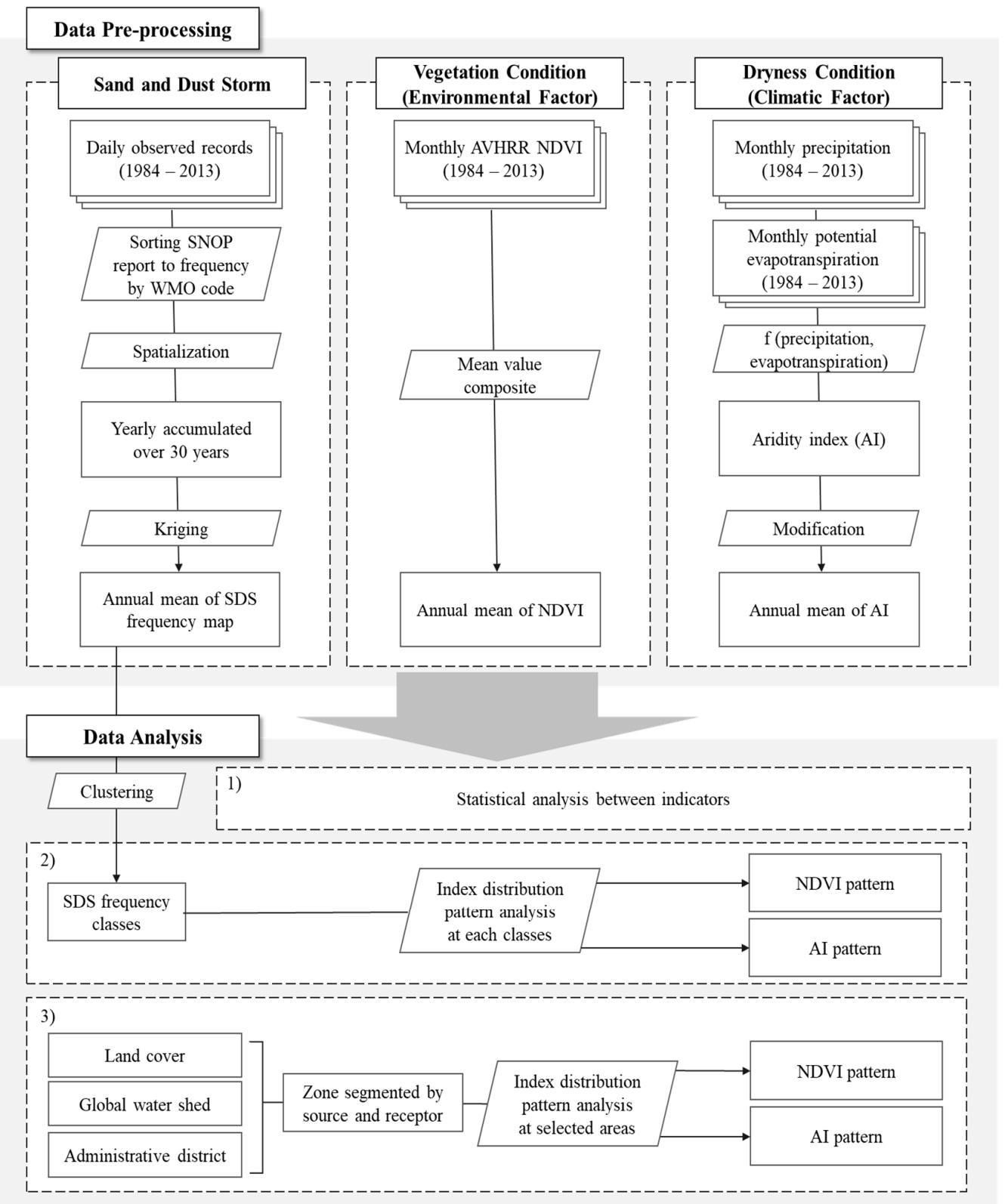

Figure 2. Research flow chart for understanding the environmental conditions linked to Sand and Dust Storm (SDS).

\subsubsection{Meteorological Dataset Preprocessing}

The SYNOP reports were sorted by SDS relevant WMO weather codes. If a WMO code (Table 2) was observed at least once out of eight times a day, we assumed that SDS event occurred [62]. The daily 
SDS events of each station location were aggregated, and this location information was spatialized as points with the sum of daily SDS events, compiling an annual SDS frequency. The annual SDS frequency points were made compatible with other spatial datasets via interpolation using the kriging method $[52,63]$.

Table 2. World Meteorological Organization (WMO) weather codes 4677 for relevant SDS (Source: WMO, 2011) [64].

\begin{tabular}{|c|c|}
\hline SYNOP Code & Weather Description \\
\hline 06 & $\begin{array}{l}\text { Widespread dust in suspension in the air, not raised by wind at or near the station } \\
\text { at the time of observation. }\end{array}$ \\
\hline 07 & $\begin{array}{l}\text { Dust or sand raised by wind at or near the station at the time of observation, but } \\
\text { not well-developed dust whirl or sand whirl, and no dust storm or sandstorm } \\
\text { seen; or, in the case of ships, blowing spray at the station. }\end{array}$ \\
\hline 08 & $\begin{array}{l}\text { Well-developed dust or sand whirl seen at or near the station during the } \\
\text { preceding hour or at the time of observation, but no dust storm or sandstorm. }\end{array}$ \\
\hline 09 & $\begin{array}{l}\text { Dust storm or sandstorm within sight at the time of observation, or at the station } \\
\text { during the preceding hour. }\end{array}$ \\
\hline 30 & $\begin{array}{c}\text { Slight or moderate dust storm or sandstorm — has decreased during the preceding } \\
\text { hour. }\end{array}$ \\
\hline 31 & $\begin{array}{c}\text { Slight or moderate dust storm or sandstorm-no appreciable change during the } \\
\text { preceding hour. }\end{array}$ \\
\hline 32 & $\begin{array}{c}\text { Slight or moderate dust storm or sandstorm - has begun or has increased during } \\
\text { the preceding hour. }\end{array}$ \\
\hline 33 & Severe dust storm or sandstorm—has decreased during the preceding hour. \\
\hline 34 & $\begin{array}{c}\text { Severe dust storm or sandstorm }- \text { no appreciable change during the receding } \\
\text { hour. }\end{array}$ \\
\hline 35 & $\begin{array}{c}\text { Severe dust storm or sandstorm—has begun or has increased during the } \\
\text { preceding hour. }\end{array}$ \\
\hline 98 & Thunderstorm combined with dust/sandstorm at time of observation. \\
\hline
\end{tabular}

\subsubsection{Statistical Analysis between Indicators}

The relationship among the annual mean of SDS frequency map, NDVI, and AI was analyzed using the Pearson correlation coefficient and multiple regression analysis over 30 years. Multiple regression analysis has been used in general to identify the causal relationship between variables [63], and, in particular, to analyze the relationship between SDS and environmental characteristics in China and Mongolia [5,65]. For statistical analysis, approximately 250,000 sample points were generated from the whole study area, from which the values of the variable were extracted. Multiple regression analysis was performed to identify the impact of the SDS frequency on the vegetation and dryness based on the extracted values.

\subsubsection{Spatial Analysis between Indicators}

The annual mean of the NDVI and AI were spatially extracted based on the boundaries of each class and areas. First, the annual means of the SDS frequency were classified into five classes by the Jenks optimization method, which is a data clustering method for determining best arrangement of values [66], to identify phased SDS impact. Second, four main representative spots, Caspian Sea and Aral Sea zone in Central Asia $[67,68]$ and Gobi Desert and Taklamakan Desert zone in East Asia $[13,69]$ were selected, for identifying impact regional differences. The selected zones were divided into source and receptor, considering environmental and sociopolicy sorting by land cover types (bare land), global watershed, and administrative districts. Since the study areas are in the path of the westerly jet-stream [70], the zones were divided into source and receptor, and the northeastern, eastern, and southeastern regions of the source area were selected as potential receptor areas.

The range of classes is characterized by a distributed range of values. Subsequently, the distribution of the value of NDVI and AI was identified according to the main source and receptor. 


\section{Results}

\subsection{Statistical Analysis between SDS, NDVI, and AI}

To understand how the SDS frequency is related to vegetation and dryness, spatially distributed annual mean of NDVI, AI, and SDS frequency during the chosen 30 years were produced (Figure 3). The spatial distributions of each index were represented based on relative values from the perspective of northern hemisphere of MLR. Basically, NDVI and AI spatially represented similar patterns in both Central Asia and East Asia. While the SDS frequency varies spatially in MLR, nearby Taklamakan Desert in East Asia has observed up to 61 records, nearby the Caspian Sea and Aral Sea in Central Asia observed 20-29 records per year. Therefore, it can be inferred that both regions suffered severe SDS damage on average for 30 years. According to Indoitu et al. [39], the dust storm generally records 10-60 days/year in China.

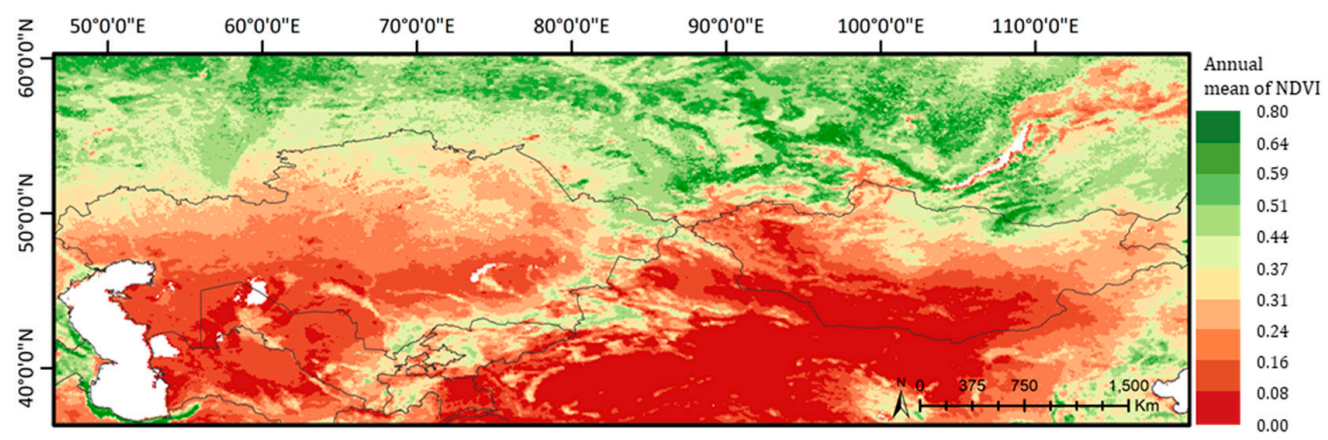

(a)

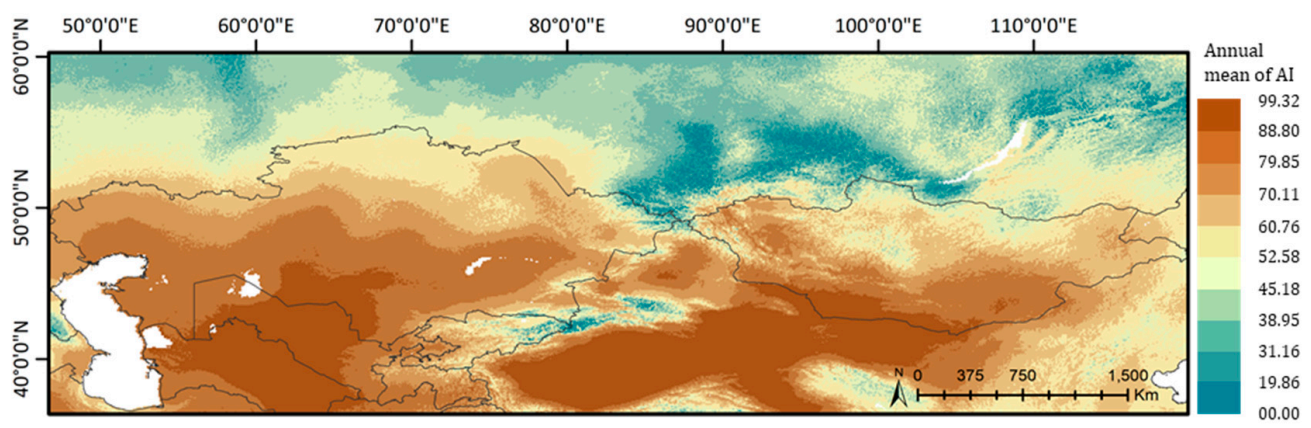

(b)

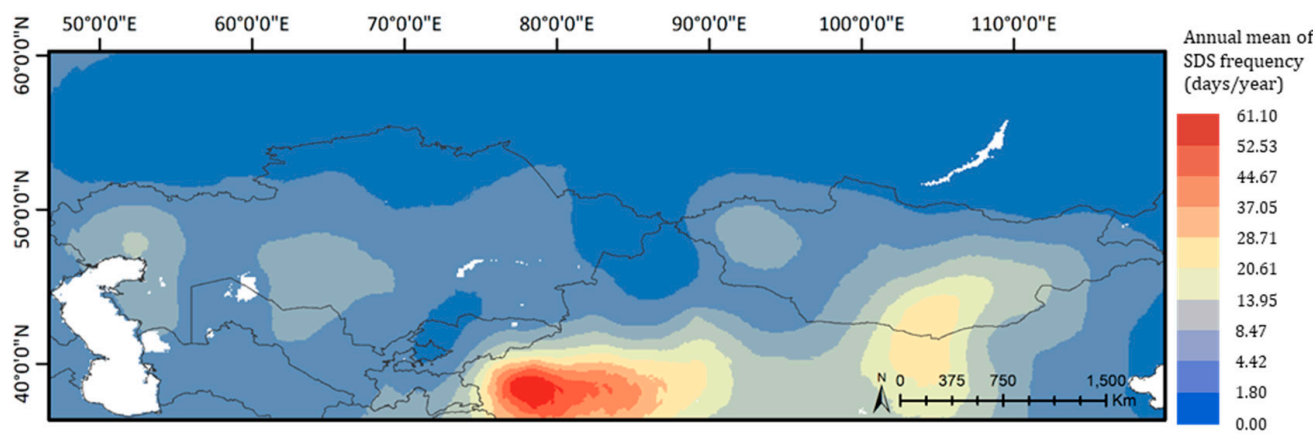

(c)

Figure 3. Annual mean distribution of (a) Normalized Difference Vegetation Index (NDVI), (b) Aridity Index (AI), and (c) SDS frequency. 
The values were extracted for each variable and were used for assessing the Pearson correlation coefficient and multiple regression analysis. The correlation coefficient was statistically significant ( $p$ $<0.0001)$ and revealed that the NDVI was negatively correlated $(-0.1916)$ and the AI was positively correlated (0.4726) with the SDS frequency (Table 3).

Table 3. Correlation of SDS, Normalized Difference Vegetation Index (NDVI), and Aridity Index (AI) over the study region.

\begin{tabular}{cccc}
\hline & SDS & NDVI & AI \\
\hline SDS & 1 & & \\
NDVI & -0.1916 & 1 & \\
AI & 0.4726 & -0.3322 & 1 \\
\hline
\end{tabular}

The relationship pattern of the NDVI and AI with the SDS frequency was shown in the scatter plots as presented in Figure 4. The overall trend showed high values of the SDS frequency at low values of the NDVI and high values of the AI, respectively. The relationship trends of these three indicator variables did not show any dependence on the region and time-series change.

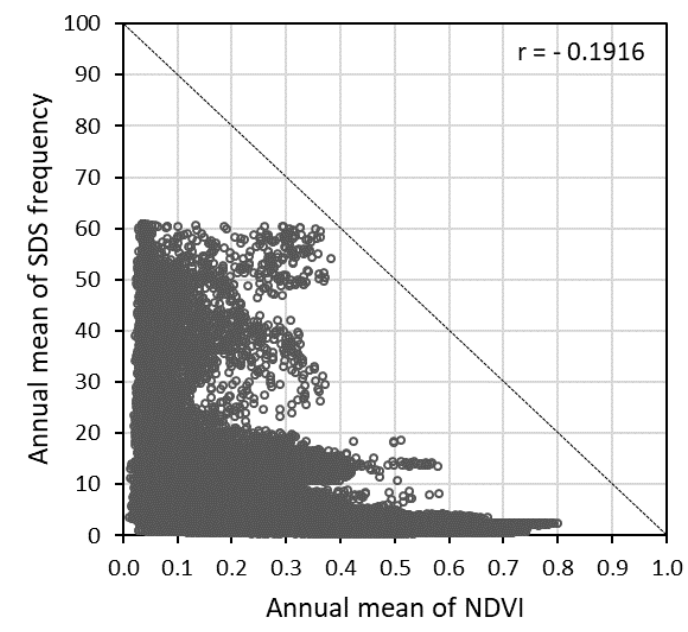

(a)

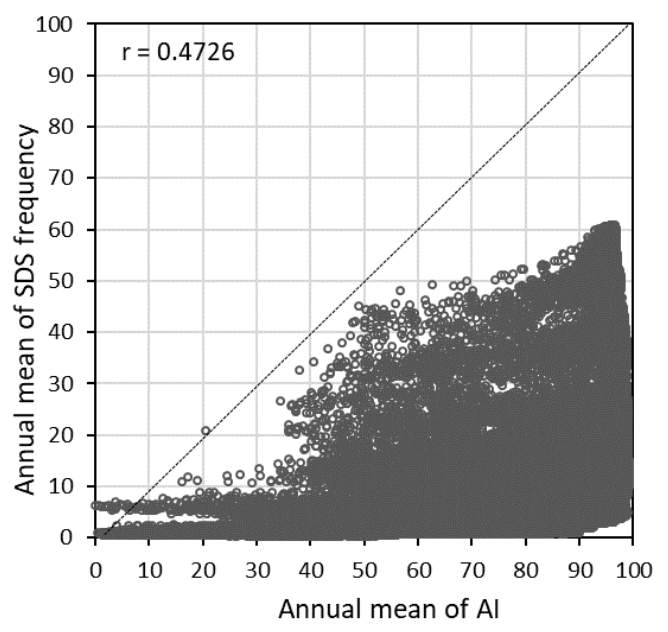

(b)

Figure 4. Trends of the (a) SDS frequency and NDVI and (b) SDS frequency and AI.

Further, the multiple regression analysis indicated that the annual mean values of the NDVI and AI were statistically significantly correlated with the SDS frequency ( $p$-value $<0.0001$ ), and the coefficient of determination (R2) was 0.2247 (Table 4).

Table 4. Multiple regression of SDS frequency, NDVI, and AI over the study region.

\begin{tabular}{ccccc}
\hline Variable & Parameter Estimate & Standard Error & t Value & $\operatorname{Pr}>|\mathbf{t}|$ \\
\hline Intercept & -5.6072 & 0.0495 & -113.27 & $<0001$ \\
AI & 0.1679 & 0.0006 & 240.63 & $<0001$ \\
NDVI & -0.6566 & 0.0322 & -20.37 & $<0001$ \\
\hline \multicolumn{5}{c}{$\operatorname{Pr}>\mathrm{F} \leq 0.001 \mathrm{R}^{2}=0.2247}$.
\end{tabular}

These relationships allow us to describe the SDS frequency with NDVI and AI. The results imply that the SDS frequency increases when the areas are drier and the poor vegetation condition. Likewise, as the land vegetation cover and moisture increased, the probability of SDS occurrences can be decreased, due to a higher wind threshold [28]. Sofue et al. [29] identified the relationship 
between the NDVI and the SDS frequency was negative, and the mean of the $\mathrm{R}^{2}$ was 0.19 in Gobi Desert, although it varied from region to region. In addition, Guan et al. [52] showed the high SDS frequency regions were correlated with low vegetation coverage areas, and the correlation coefficient ranged from -0.3 to 0 in source of SDS in North China.

The relationship among NDVI, AI, and SDS frequency represents a similar level of correlation coefficient from the macroscale in MLR with previous studies, and it could be inferred for and applied to Central Asia, where SDS researchers have given less attention to the relationship with environmental factors.

\subsection{Identifying the Phased SDS Impact on the NDVI and AI}

The annual mean of the SDS frequency was divided into five classes based on the relative value of SDS in MLR, according to the Jenks optimization method. In Figure 5, the red area was highlighted as the constantly affected class and represented a relatively high value of the annual mean SDS frequency, while the blue area showed a rarely affected class and a relatively low value. The entire study area was basically an area where high SDS occurrence and SDS damage except rarely affected class (blue area).

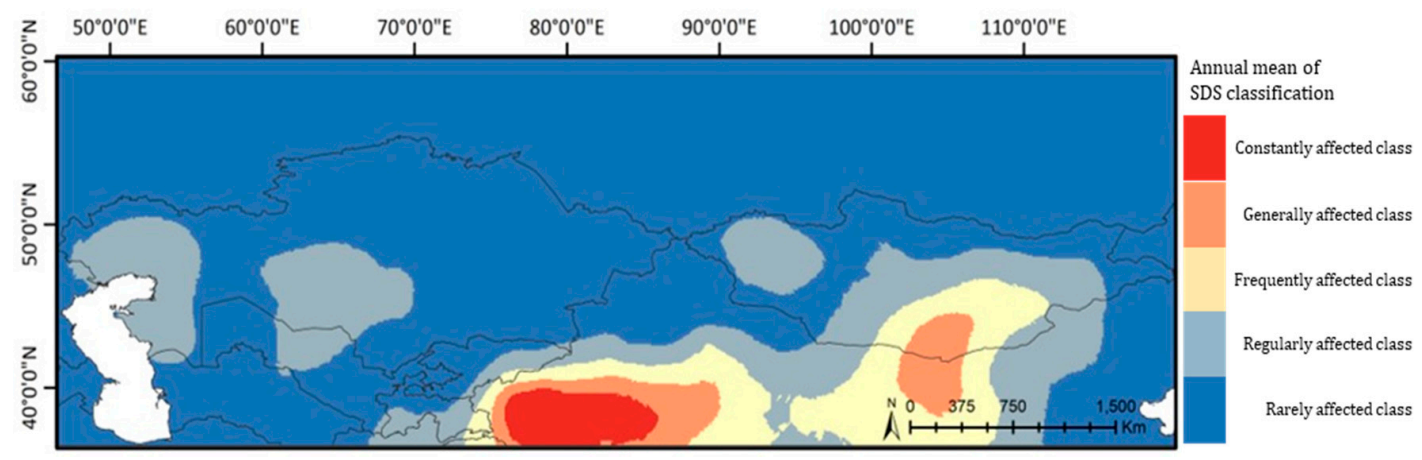

Figure 5. Annual mean of SDS frequency classification over 30 years.

Mostly affected classes were found in the nearest desert areas in each East Asia and Central Asia, respectively, and they were relatively concentrated in the East Asia from perspective of MLR. The overall pattern of the SDS classes was similar to that reported in previous SDS monitoring results $[30,57]$. Surrounding the western part of Central Asia (including the Aral Sea and Caspian Sea), southern Mongolia (including the Gobi Desert), and northwestern China (including the Taklamakan Desert) is the SDS center source and the significantly damaged region [12,59]. In this study, we identified the relationship between each indicator presented in Section 3.1, assumed a higher relation of vegetation-SDS frequency and dryness-SDS frequency in areas with higher exposure to the SDS, and analyzed the distribution of NDVI and AI based on the SDS classes.

In Figure 6, the x-axis represents the annual mean NDVI, and the y-axis represents the annual mean AI. The NDVI and AI distributions showed significant differences, according to the SDS classes. In particular, the most severe SDS class trend was expressed by a pattern that showcases reduced vegetation cover (lower value of NDVI) and more dryness (higher value of AI).

The rarely affected class included most of the areas that are affected infrequently by SDS, with an NDVI ranging from 0 to 0.7 and an AI from 0 to 100. Its NDVI and AI ranges can be widely distributed as most areas contain various land covers and have been less affected by SDS. 


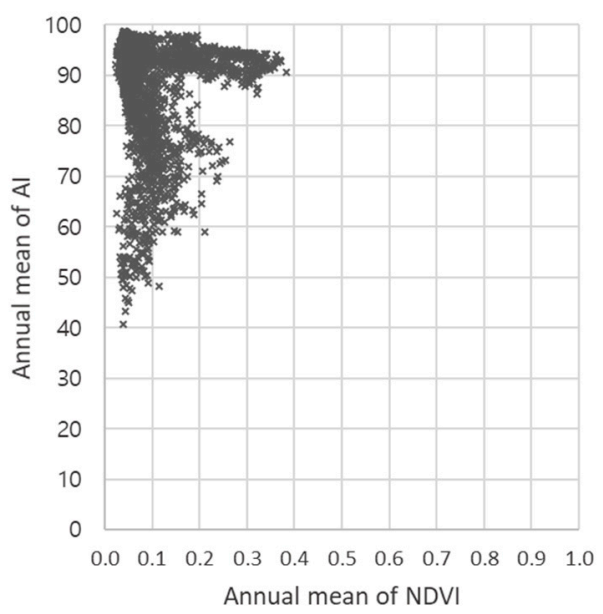

(a)

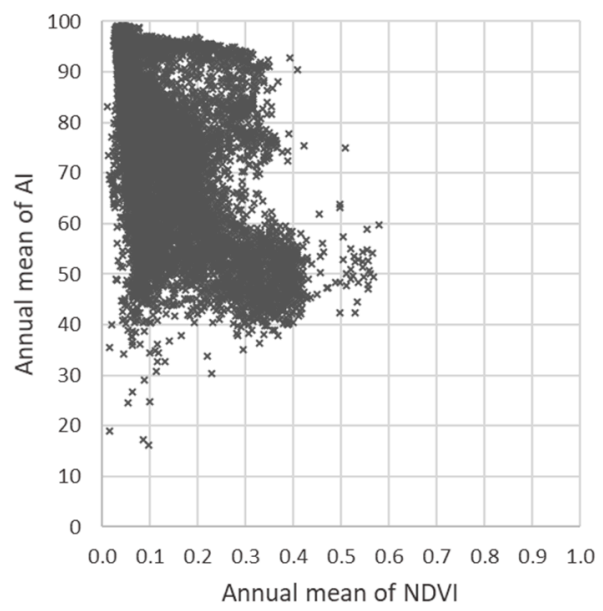

(c)

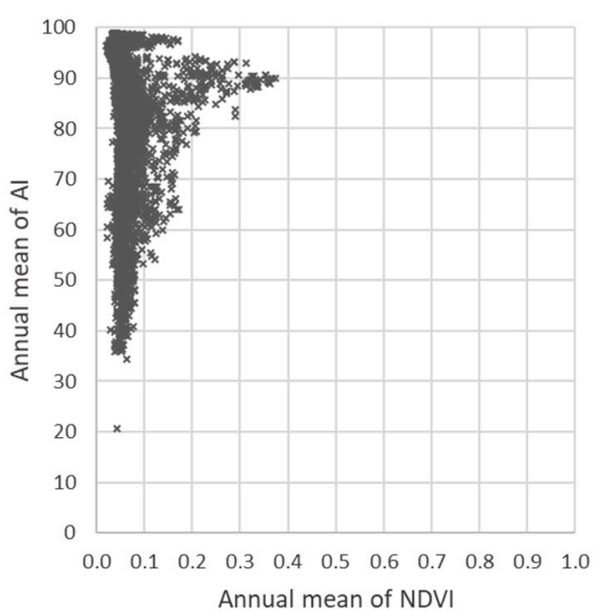

(b)

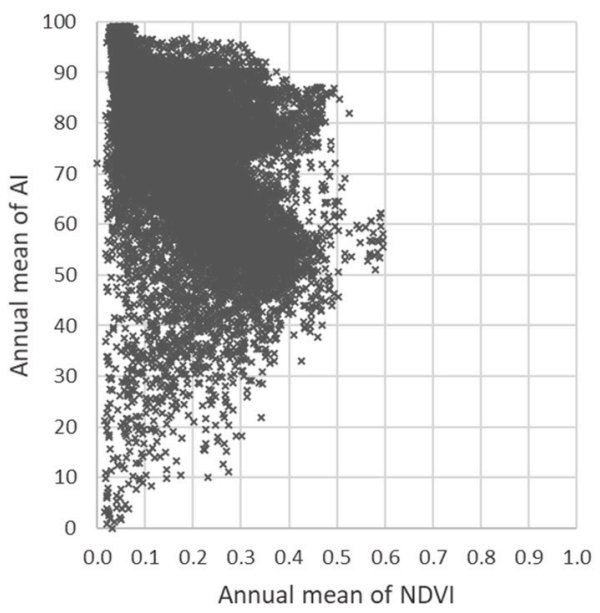

(d)

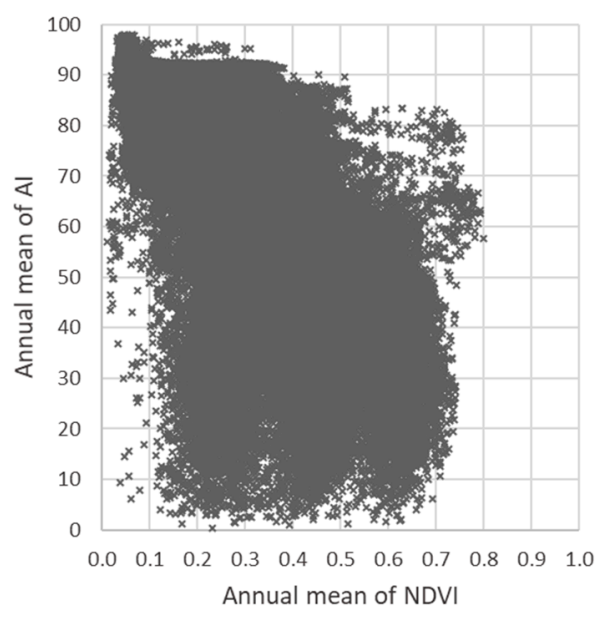

(e)

Figure 6. Distribution of NDVI and AI in entire study area by (a) constantly affected class, (b) generally affected class, (c) frequently affected class, (d) regularly affected class, and (e) rarely affected class. 
The regularly affected class exhibited relatively reduced ranges in comparison with those of the rarely affected class; the NDVI range was $0-0.45$, and the AI range was 35-100. This SDS class is detected, which is located in northern west of Caspian Sea surrounding Ryn Desert and Atyrau, and east of Aral Sea surrounding Aralkum Desert and pre-Aral Karakum Desert of Central Asia. The noticeable difference was that the excellent conditions (high NDVI and low AI), which were the characteristics of the rarely affected class, were not present. Likewise, the relatively better conditions (high NDVI or low AI), which were included in the regularly affected class, were not present for the frequently affected class, for which the NDVI range was 0-0.4 and the AI was 40-100.

An NDVI range was characterized by the generally affected class and constantly affected class under 0.35 and an AI range of approximately 50-100. These two classes include mainly Taklamakan desert, Gobi Desert, and peripheral desert progress areas (including Tarim Basin, Qaidam Basin, Alashan Plateau, etc.). Since these areas would be grouped into one characteristic, the distribution of the two classes appeared to be similar.

These results showed that the distributions of NDVI and AI change in a similar manner with the corresponding SDS class. As the SDS class worsens, the superior conditions (high NDVI and low AI) of the previous class worsen as well. In particular, the SDS class tended to change first according to NDVI values rather than AI, thus it can be inferred that vegetation conditions affect the threshold values of the initial SDS class.

\subsection{Identifying Regional Differences according to the NDVI and AI Pattern}

In this study, it was difficult to clearly distinguish between the sources and receptors. However, we attempted to characterize the distributions of NDVI and AI based on several features.

First, the representative main SDS sources and receptors were selected. The main SDS source areas were located around the northwest of Caspian and east of Aral Sea in Central Asia (surrounding Ryn Desert and Atyrau and east of Aral Sea surrounding Aralkum Desert and pre-Aral Karakum Desert) and the Gobi Desert and Taklamakan Deserts in East Asia (including Tarim Basin, Qaidam Basin, Alashan Plateau and etc.), which were mentioned in previous studies. The SDS receptors were the peripheral regions of the SDS sources, and it was selected by the segmented region. The distributions of the NDVI and AI values in each region are presented in Figure 7.

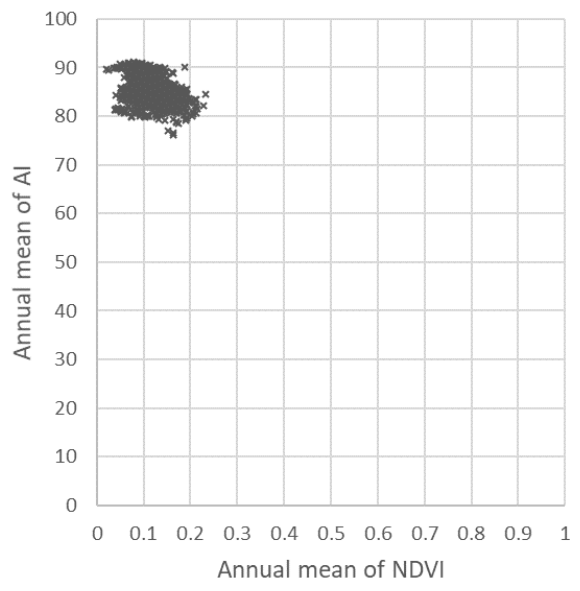

(a)

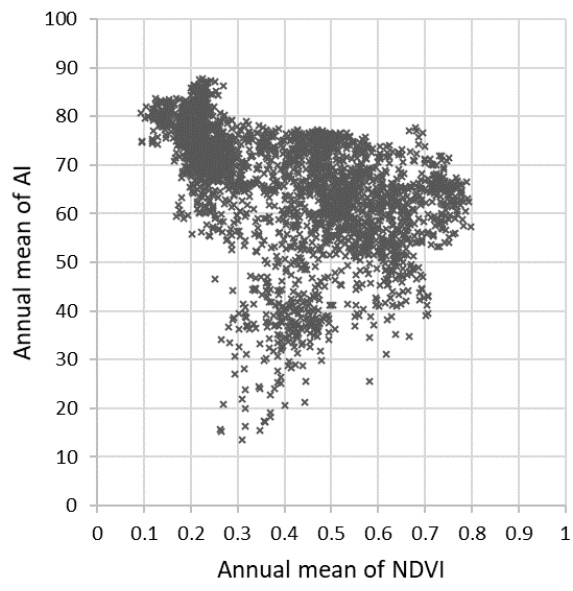

(b)

Figure 7. Cont. 


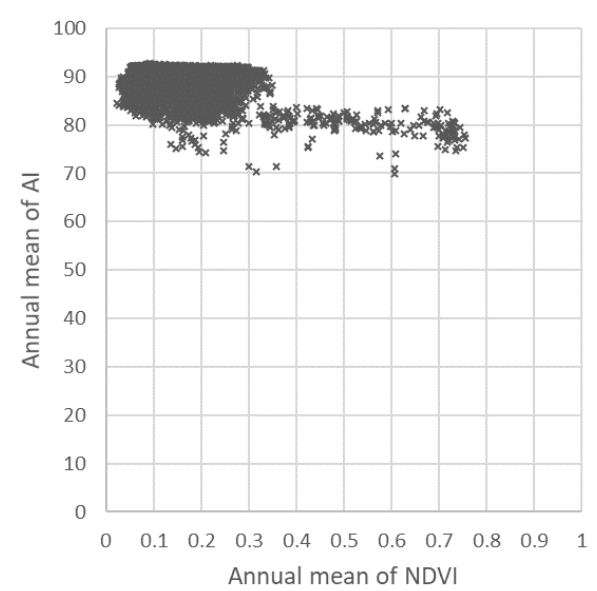

(c)

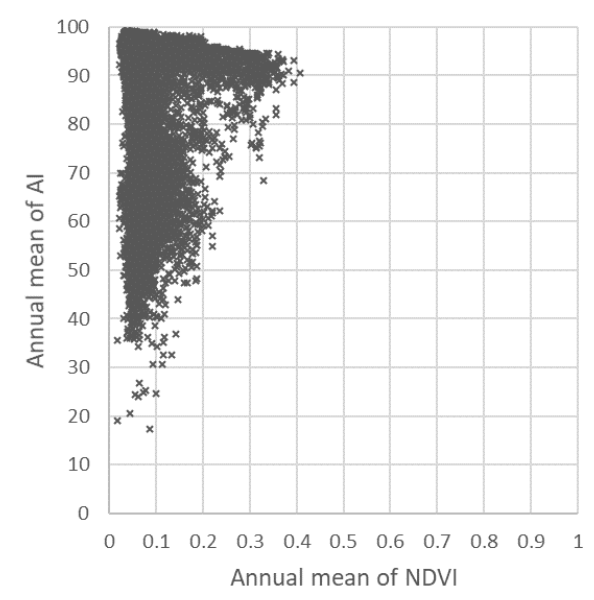

(e)

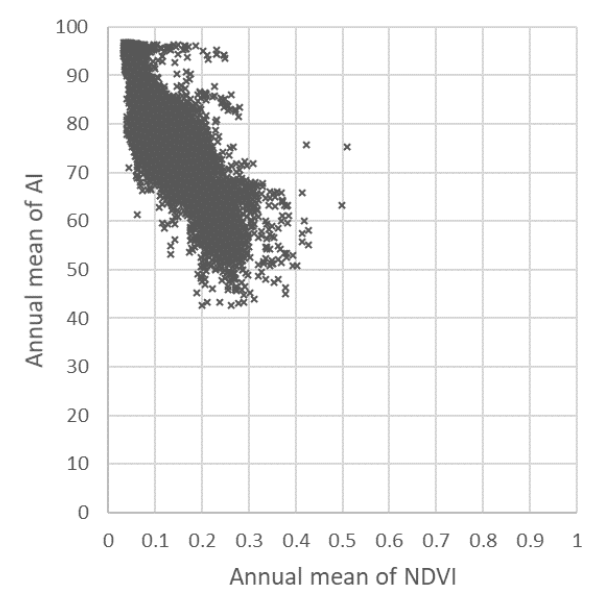

(g)

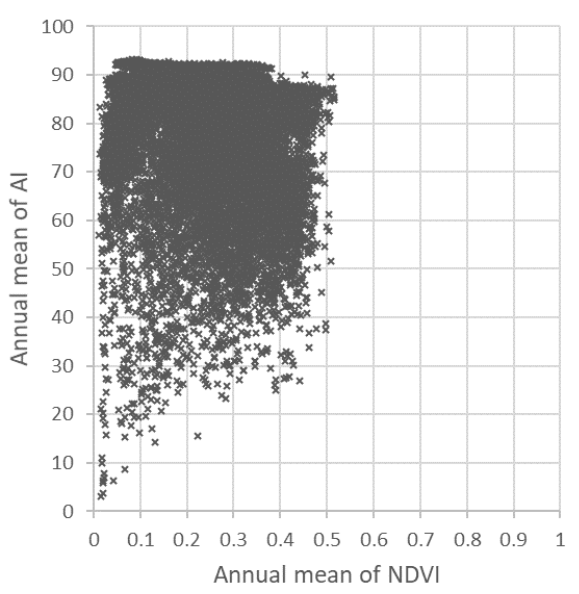

(d)

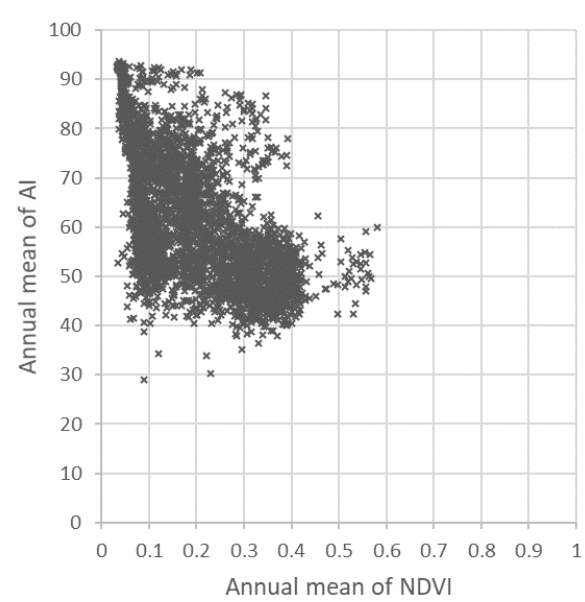

(f)

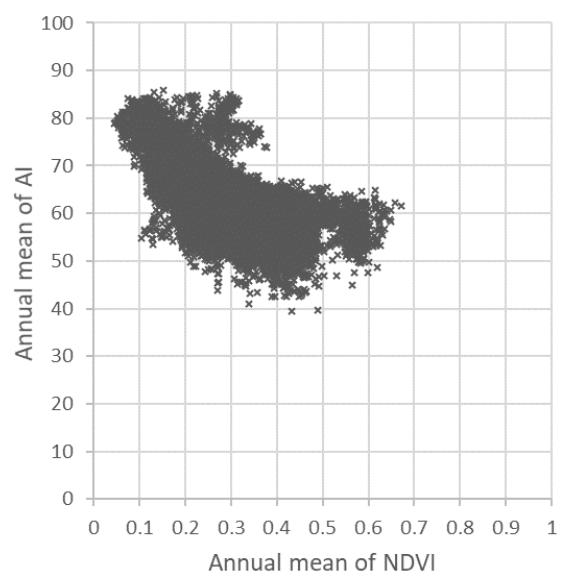

(h)

Figure 7. Distribution of NDVI and AI in Central Asia and East Asia: (a) SDS source of Caspian Sea, (b) receptor of Caspian Sea, (c) SDS source of Aral Sea, (d) SDS receptor of Aral Sea; (e) SDS source of Taklamakan Desert, (f) SDS receptor of Taklamakan Desert, (g) SDS source of Gobi Desert, and (h) SDS receptor of Gobi Desert. 
The most significant result was that the distributions of NDVI and AI were different for the sources and receptors. In particular, Central Asia region revealed significant differences of NDVI and AI distribution. As shown in Figure 7, in Central Asia, the distribution of the two indicators were shifted from the upper left to the wide central left for all the Caspian and Aral Sea sources and receptors (Figure 7a-d). For the source of the Caspian Sea areas, the NDVI was below 0.25, and AI was above 80 (Figure 7a). For the surrounding receptor areas of the Caspian Sea, the range observed for NDVI was within $0.1-0.8$ and for AI, range was 15-90 (Figure 7b). Similarly, the NDVI ranged from 0 to 0.35 , and AI exceeded 80 for the source of the Aral Sea (Figure 7c), and the NDVI and AI ranges were below 0.5 and 25-90, respectively, for the receptor areas of the Aral Sea (Figure 7d). This result clearly showed the differences of environmental and climate spatial distribution in the SDS sources and receptors. The SDS sources revealed typical characteristics, which is dryness and rare vegetation, of desert and indicate conditions under which soil erosion can easily occur. On the other hand, the wide range of environmental and climate factors was shown in SDS receptors affected by SDS from sources.

In case of East Asia, the distributions of source and receptor were not clearly distinguished compared to Central Asia. The source areas of SDS had a similar range of distribution for NDVI $(0.0-0.35)$ and $\mathrm{AI}(40-100)$ and spread in a wider range in the surrounding receptor areas (Figure 7e-h). In particular, the range of NDVI and AI in source areas were relatively spread compared to source areas of Central Asia. This implies that the results of afforestation and restoration project on the edge of the deserts designed to reduce the SDS impact was reflected on the range of NDVI, and the dryness was also considered to reflect the mixed characteristics of both arid and semiarid regions. In fact, China and Mongolia have effectively improved their vegetation conditions since the projects started, and they have contributed to reduction of SDS occurrence by reducing the wind speed in a positive aspect [18].

The most significant aspect of the entire area was that the NDVI and AI distributions showed the widen pattern as the source area changes to a receptor area. These results were also consistent, compared with the results described in Section 3.2. This means that the mainly observed SDS areas on average have high dryness and few or poor vegetation characteristics. These characteristics are associated with distinct characteristics in the source areas of Central Asia and East Asia respectably, leading to conditions where SDS can easily occur, whereas the receptor areas can be diverse in environmental and climate conditions relatively and are a potential risk area where loss of vegetation and soil has progressed or may progress by negative SDS impact on the environment. By these results, we can suggest improving the environmental restoration by controllable infrastructure or socioeconomic policy factors are needed for enhancing adaptive capacity to SDS in Central Asia.

\section{Discussion}

In this study, we understood the relationship between the annual mean SDS frequency, vegetation cover, and dryness in the MLR. We identified and characterized environmental conditions based on the phased SDS impact and regional differences of source and receptor using only vegetation cover and climate data from remote sensing. The potential risk of the SDS can be established by these approaches using the relationship and distribution of representative vegetation condition and dryness indicators in insufficiently studied and inaccessible area.

This study showed the applicability of satellite-based NDVI and AI on the SDS impact on the vast MLR. As the SDS classes worsened and approached the sources, the vegetation gradually decreased and dryness gradually increased. This represented that more exposure to the effects of SDS may cause more dryness and loss of vegetation cover, intensifying further the SDS impacts. These results imply that, as mentioned in previous studies, the SDS impacts may continue to increase in areas (west of the Caspian Sea surrounding Ryn Desert and Atyrau, and east of the Aral Sea surrounding Aralkum Desert and pre-Aral Karakum Desert in Central Asia) where exposure is repeated, as a result of a negative cycle [5].

In addition, the characteristics of the SDS sources and receptors in Central Asia and East Asia have shown a pattern that is generally consistent with the characteristics of high exposed areas to 
SDS. Therefore, the SDS source area was affected at the same time as the SDS outbreak, similar to highly exposed SDS classes. As the SDS receptors contain diverse land cover types including around desert areas, the NDVI and AI ranges appear wider than source areas and are relatively not thoroughly characterized. However, since SDS can move large areas, the SDS receptor areas can become potential risk areas where vegetation loss and soil erosion can occur continuously, affected by SDS [3,34]. Since remote sensing technology can monitor continuous land surface changes and accumulate information that can be connected with other environmental industry, it is advantageous to use this technology to be able to systematically adapt and manage the SDS, which has characteristics of the event [71].

To reduce the occurrence and impact of the SDS, the vegetation factor, which can be controlled by humans, must be improved as the adaptive measures, rather than the climate conditions [29]. Generally, forests contribute to protecting erosion of land and soil, improving air quality, and producing fertile and productive land [72]. Therefore, this study emphasizes the importance of improving environmental infrastructure in connection with reforestation and restoration project, early warning system for SDS adaptation, and policy proposal related to SDS. Indeed, East Asia actively continues making their efforts to mitigate and adapt to SDS by internal and external cooperation, and this approach needs to be applied in Central Asia. Although there are still controversies about effectivity of vegetation due to various factors causing SDS, improvement of vegetation cover is the most basic and ecological approach for reducing SDS intensity and concentration $[39,61,65,66]$. Therefore, we expect to be able to prepare for the risk of SDS damages in advance, by establishing potential vegetation areas and restoration vegetation near the source area to cope with soil erosion and land degradation by increasing the water content and by afforestation of windbreak to prevent the floating SDS around receptors.

The observed SDS records are essential to identify the spatial-temporal distribution, relationship with other variables, and developing adaptive capacity. However, there were limitation of accessible SDS relevant data. In previous studies, national self-observed SDS data was used for each site of East Asia and Central Asia [25,33-35,73,74]. However, these datasets did not cover macroscale across countries, and data limitations have been constantly mentioned in previous studies. Therefore, due to inaccessibility to relevant national self-SDS data, in this study, the observed SDS data of long-term global levels and data on typical vegetation and dryness were used for application and utilization on the MLR. In addition, we focused on the facts observed from occurring SDS and identified the impact of continuous exposure to SDS. Since the trends of each relationship were applied from the macroscale in the vast MLR and showed spatially stretched, the result may reveal less impact on Central Asia. This result represents the relative comparison of SDS frequency which is expressed spatially according to the macroscale from MLR. In future studies, a variety of indicators exclusively targeted at microscale such as inter-Central Asia will contribute to detail the SDS impact results. A macroscale SDS study provides the basis for multinational cooperation on SDS. This study can contribute to DRR in Sendai Framework by providing science-based analysis result for decision-makers from MLR perspective.

Conclusively, it is important to improve the feedback mechanism by vegetation restoration and reforestation in Central Asia, which is a potential SDS risk area, following the efforts made in Mongolia and China. Ultimately, this study can support policymakers to prepare effectively for reducing disaster risk, mitigating human suffering, and lessening the socioeconomic and environmental damages.

\section{Conclusions}

This study identified the applicability of methodology to assess SDS in Central Asia by comparing in various ways the relationship between the MLR annual SDS frequency and the vegetation status and dryness. In particular, the most representative satellite-based climate and environmental indices were used to understand the relationship of the impact with the SDS according to the range of their values, and hence provide essential information by linking the regional SDS source and SDS receptor zones. According to the result, the SDS sources that are highly exposed to SDS have poor vegetation and high dryness characteristics, whereas the surrounding receptor have expanded the range of value of vegetation and dryness according to a degree of exposure to SDS. In particular, the nearby Aral 
Sea and Caspian Sea can be considered as active sources in Central Asia. Moreover, the settlement area of Central Asia is closer to the SDS risk area than in East Asia, this area would be actually more vulnerable to SDS damage and potentially more damaging. In Central Asia, SDS information has mainly relied on SDS records, but it is necessary to consider additional SDS relevant satellite-based land surface indices that can be continuously monitored in order to prepare for damage caused by SDS in advance since generally SDS are recorded after a disaster occurrence.

To reduce the SDS risk in Central Asia where accessible data and information are insufficient, SDS analysis using climate and environmental conditions was conducted. In particular, spatial analysis attempted a variety of approaches by performing both spatial distributions of phased SDS impact and analysis according to the detailed regional differences. The ranges of climate and environmental conditions are closely related to the frequency of SDS and can help to prioritize specific SDS risk areas. In addition, the general verified climate and environmental indices and global station data were used to ensure the reliability of this study. The macrolevel approach in the MLR perspective can support decision-making at multinational scale cooperation. By the methodology presented in terms of supporting recently introduced International Central Asia SDS project partners, priority actual and potential SDS risk regions can be identified. Then, by increasing the resolution of study area, it can be applied to the additional regions to save time and cost for macro level cooperation. This study shows the applicability of various methods in this field by linking regional differences by comprehensive climate environmental analysis in macroscale SDS study. Based on this information, each country will have a foundation for effectively establishing strategies such as predicting potential risk areas for SDS and planning adaptive pathways to achieve disaster risk reduction. Furthermore, building adaptive capacity of SDS can contribute to future environmental management solutions and political pathways in the MLR.

Author Contributions: Conceptualization, E.P.; data curation, H.-W.J. and S.L.; formal analysis, E.P.; investigation, J.K., S.J.K., S.P., and C.-H.L.; methodology, E.P., J.K., and C.S.; supervision, W.-K.L.; validation, H.-W.J., and S.L.; writing—original draft, E.P.; writing—review and editing, J.K., C.S., H.-W.J., S.L., S.J.K., S.P., C.-H.L., and W.-K.L. All authors contributed equally to editing and revising of this review. All authors have read and agreed to the published version of the manuscript.

Funding: This research was funded by the National Research Foundation of Korea (NRF) funded by the Ministry of Science, ICT \& Future Planning (Grant number: 2018K1A3A7A03089842) and the National Research Foundation of Korea (NRF) grant funded by the Korea government (MSIT) (No. 2018R1A2B6005682).

Acknowledgments: This work was supported by the United Nations Economic and Social Commission for Asia and the Pacific (ESCAP) (No. 2017-0014).

Conflicts of Interest: The authors declare no conflict of interest.

\section{References}

1. Moon, J.; Lee, W.K.; Song, C.; Lee, S.G.; Heo, S.B.; Shvidenko, A.; Kraxner, F.; Lamchin, M.E.; Lee, J.; Zhu, Y.; et al. An Introduction to Mid-Latitude Ecotone: Sustainability and environmental challenges. Sib. J. For. Sci. 2017, 6, 41-51. [CrossRef]

2. Prospero, J.M.; Ginoux, P.; Torres, O.; Nicholson, S.E.; Gill, T.E. Environmental characterization of global sources of atmospheric soil dust identified with the Nimbus 7 Total Ozone Mapping Spectrometer (TOMS) absorbing aerosol product. Rev. Geophys. 2002, 40, 1002. [CrossRef]

3. Middleton, N.; Kang, U. Sand and dust storms: Impact mitigation. Sustainability 2017, 9, 1053. [CrossRef]

4. Song, C.; Pietsch, S.A.; Kim, M.; Cha, S.; Park, E.; Shvidenko, A.; Schepaschenko, D.; Kraxner, F.; Lee, W.-K. Assessing forest ecosystems across the vertical edge of the Mid-Latitude Ecotone using the BioGeoChemistry Management Model (BGC-MAN). Forests 2019, 10, 523. [CrossRef]

5. $\mathrm{Xu}, \mathrm{J}$. Sand-dust storms in and around the Ordos Plateau of China as influenced by land use change and desertification. Catena 2006, 65, 279-284. [CrossRef]

6. Ahmady-Birgani, H.; McQueen, K.G.; Moeinaddini, M.; Naseri, H. Sand dune encroachment and desertification processes of the rigboland Sand Sea, Central Iran. Sci. Rep. 2017, 7, 1523. [CrossRef] 
7. Cao, H.; Fu, C.; Zhang, W.; Liu, J. Characterizing sand and dust storms (SDS) intensity in China based on meteorological data. Sustainability 2018, 10, 2372. [CrossRef]

8. Middleton, N.; Tozer, P.; Tozer, B. Sand and dust storms: Underrated natural hazards. Disasters 2019, 43, 390-409. [CrossRef]

9. Goudie, A.S. Dust Storms and Human Health. In Extreme Weather Events and Human Health; Akhtar, R., Ed.; Springer: Cham, Switzerland, 2020. [CrossRef]

10. UNEP; WMO; UNCCD. Global Assessment of Sand and Dust Storms, 1st ed.; United Nations Environment Programme: Nairobi, Kenya, 2016.

11. Youlin, Y.; Squires, V.; Qi, L. Global Alarm: Dust and Sandstorms from the World's Drylands; United Nations Convention to Combat Desertification (UNCCD): Bangkok, Thailand, 2002; Volume 345.

12. Aili, A.; Oanh, N.T.K. Effects of dust storm on public health in desert fringe area: Case study of northeast edge of Taklimakan Desert, China. Atmos. Pollut. Res. 2015, 6, 805-814. [CrossRef]

13. Jugder, D.; Shinoda, M.; Sugimoto, N.; Matsui, I.; Nishikawa, M.; Park, S.U.; Chun, Y.S.; Park, M.S. Spatial and temporal variations of dust concentrations in the Gobi Desert of Mongolia. Global Planet Chang. 2011, 78, 14-22. [CrossRef]

14. Abdullaev, S.F.; Sokolik, I.N. Main Characteristics of Dust Storms and Their Radiative Impacts: With a Focus on Tajikistan. J. Atmos. Sci. 2019, 2, 2. [CrossRef]

15. Goudie, A.S. Dust-storm source areas determined by the total ozone monitoring spectrometer and surface observations. Ann. Am. Assoc. Geogr. 2003, 93, 297-313. [CrossRef]

16. Ginoux, P.; Prospero, J.M.; Gill, T.E.; Hsu, N.C.; Zhao, M. Global-scale attribution of anthropogenic and natural dust sources and their emission rates based on MODIS Deep Blue aerosol products. Rev. Geophys. 2012, 50. [CrossRef]

17. Song, Z. A numerical simulation of dust storms in China. Environ. Model. Softw. 2014, 19, 141-151. [CrossRef]

18. UNESCO. Map of the World Distribution of Arid Regions: Explanatory Note, 1st ed.; UNESCO: Paris, France, 1979; pp. 1-48.

19. Tsolmon, R.; Ochirkhuyag, L.; Sternberg, T. Monitoring the source of trans-national dust storms in north east Asia. Int. J. Digit. Earth 2008, 1, 119-129. [CrossRef]

20. Qu, J.; Hao, X.; Kafatos, M.; Wang, L. Asian dust storm monitoring combining Terra and Aqua MODIS SRB measurements. IEEE Geosci. Remote Sens. Lett. 2016, 3, 484-486. [CrossRef]

21. Kazi, A.K.; Nagatani, I.; Kawano, K.; Kudoh, J.I. Development of a new dust index NDLI for Asian dust extraction system based on Aqua MODIS data and monitoring of trans-boundary Asian dust events in Japan. Int. J. Remote Sens. 2019, 40, 1030-1047. [CrossRef]

22. Nagatani, I.; Kudoh, J.-I. Monitoring result of 2013 and 2014 transboundary Asian dust event in Japan using MODIS dust index. Int. J. Remote Sens. 2019, 40, 1030-1047. [CrossRef]

23. Samadi, M.; Boloorani, A.D.; Alavipanah, S.K.; Mohamadi, H.; Najafi, M.S. Global dust Detection Index (GDDI); A new remotely sensed methodology for dust storms detection. J. Environ. Health Sci. Eng. 2014, 12, 20. [CrossRef]

24. An, L.; Che, H.; Xue, M.; Zhang, T.; Wang, H.; Wang, Y.; Zhou, C.; Zhao, H.; Gui, K.; Zheng, Y.; et al. Temporal and spatial variations in sand and dust storm events in East Asia from 2007 to 2016: Relationships with surface conditions and climate change. Sci. Total Environ. 2018, 633, 452-462. [CrossRef]

25. Kang, L.; Huang, J.; Chen, S.; Wang, X. Long-term trends of dust events over Tibetan Plateau during 1961-2010. Atmos. Environ. 2016, 125, 188-198. [CrossRef]

26. Wang, X.; Dong, Z.; Zhang, J.; Liu, L. Modern dust storms in China: An overview. J. Arid Environ. 2014, 58, 559-574. [CrossRef]

27. Sun, J.; Zhang, M.; Liu, T. Spatial and temporal characteristics of dust storms in China and its surrounding regions, 1960-1999: Relations to source area and climate. J. Geophys. Res. Atmos. 2001, 106, 10325-10333. [CrossRef]

28. Xu, X.; Levy, J.K.; Zhaohui, L.; Hong, C. An investigation of sand-dust storm events and land surface characteristics in China using NOAA NDVI data. Glob. Planet Chang. 2006, 52, 182-196. [CrossRef]

29. Sofue, Y.; Hoshino, B.; Demura, Y.; Kai, K.; Baba, K.; Nduati, E.; Kondoh, A.; Sternberg, T. Satellite monitoring of vegetation response to precipitation and dust storm outbreaks in Gobi Desert regions. Land 2018, 7, 19. [CrossRef] 
30. Yang, Y.Q.; Hou, Q.; Zhou, C.H.; Liu, H.L.; Wang, Y.Q.; Niu, T. Sand/dust storm processes in Northeast Asia and associated large-scale circulations. Atmos. Chem. Phys. 2008, 8, 25-33. [CrossRef]

31. Zhang, K.; Qu, J.; Zu, R.; Fang, H. Temporal variations of sandstorms in Minqin oasis during 1954-2000. Environ. Geol. 2005, 49, 332-338. [CrossRef]

32. Wang, X.; Lu, C.; Fang, J.; Shen, Y. Implications for development of grain-for-green policy based on cropland suitability evaluation in desertification-affected north China. Land Use Policy 2007, 24, 417-424. [CrossRef]

33. Wang, X.M.; Zhang, C.X.; Hasi, E.; Dong, Z.B. Has the Three Norths Forest Shelterbelt Program solved the desertification and dust storm problems in arid and semiarid China? J. Arid Environ. 2010, 74, 13-22. [CrossRef]

34. Tan, M.; Li, X. Does the Green Great Wall effectively decrease dust storm intensity in China? A study based on NOAA NDVI and weather station data. Land Use Policy 2015, 43, 42-47. [CrossRef]

35. Fan, B.; Guo, L.; Li, N.; Chen, J.; Lin, H.; Zhang, X.; Shen, M.; Rao, Y.; Wang, C.; Ma, L. Earlier vegetation green-up has reduced spring dust storms. Sci. Rep. 2014, 4, 6479. [CrossRef] [PubMed]

36. Middleton, N. Rangeland management and climate hazards in drylands: Dust storms, desertification and the overgrazing debate. Nat. Hazards 2018, 92, 57-70. [CrossRef]

37. Dickerson, P.W. A Caspian chronicle: Sea level fluctuations between 1982 and 1997. In Dynamic Earth Environments: Remote Sensing Observations from Shuttle-Mir Missions, 1st ed.; Lulla, K.P., Dessinov, L.V., Eds.; John Wiley: New York, NY, USA, 2000; pp. 145-148.

38. Indoitu, R.; Orlovsky, L.; Orlovsky, N. Dust storms in Middle Asia: Spatial and temporal variations. WIT Trans. Ecol. Environ. 2009, 122, 353-364. [CrossRef]

39. Indoitu, R.; Orlovsky, L.; Orlovsky, N. Dust storms in Central Asia: Spatial and temporal variations. J. Arid Environ. 2012, 85, 62-70. [CrossRef]

40. Indoitu, R.; Kozhoridze, G.; Batyrbaeva, M.; Vitkovskaya, I.; Orlovsky, N.; Blumberg, D.; Orlovsky, L. Dust emission and environmental changes in the dried bottom of the Aral Sea. Aeolian Res. 2015, 17, 101-115. [CrossRef]

41. Issanova, G.; Abuduwaili, J. Dust storms in Central Asia and Kazakhstan: Regional division, frequency and seasonal distribution. In Aeolian Processes as Dust Storms in the Deserts of Central Asia and Kazakhstan; Springer: Singapore, 2017; pp. 87-109.

42. Löw, F.; Navratil, P.; Kotte, K.; Schöler, H.F.; Bubenzer, O. Remote-sensing-based analysis of landscape change in the desiccated seabed of the Aral Sea-A potential tool for assessing the hazard degree of dust and salt storms. Environ. Monit. Assess. 2013, 185, 8303-8319. [CrossRef]

43. Micklin, P.; Aladin, N.V.; Plotnikov, I. The Aral Sea, 1st ed.; Springer: Berlin, Germany, 2014; pp. 1-11.

44. Isamiddinova, D. Report on the Status of Women in Uzbekistan, 1st ed.; United Nations Development Programme: New York, NY, USA, 1999; pp. 1-80.

45. Kim, J.; Song, C.; Lee, S.; Jo, H.-W.; Park, E.; Yu, H.; Cha, S.; An, J.; Son, Y.; Khamzina, A.; et al. Identifying Potential Vegetation Establishment Areas in the Aral Sea using Satellite Images. Land Degrad. Dev. 2020. [CrossRef]

46. Lee, W.-K.; Kim, S.J.; Lee, S.J.; Park, E.; Kim, J.; Park, S.; Kim, G.; Kim, N.; Lee, W.; Shaimerdenova, A.; et al. Developing Geospatial and Statistical Indicators for DRR: A Pilot Study of Drought, Flood, Sand and Dust Storm, and Air Pollution in South Korea and Kazakhstan, 1st ed.; OJERI, eGISRS, IEE: Seoul, Korea, 2019; pp. 1-73.

47. Xi, X.; Sokolik, I.N. Dust interannual variability and trend in Central Asia from 2000 to 2014 and their climatic linkages. J. Geophys. Res. Atmos. 2015, 120, 12-175. [CrossRef]

48. Zhou, C.; Gui, H.; Hu, J.; Ke, H.; Wang, Y.; Zhang, X. Detection of new dust sources in Central/East Asia and their impact on simulations of a severe sand and dust storm. J. Geophys. Res. Atmos. 2019, 124, 10232-10247. [CrossRef]

49. Liu, A.; Wang, J.; Liu, Z.; Wang, J. Monitoring desertification in arid and semi-arid areas of China with NOAA-AVHRR and MODIS data. In Proceedings of the 2005 IEEE International Geoscience and Remote Sensing Symposium, Seoul, Korea, 29 July 2005; Volume 4, pp. 2362-2364.

50. Zolotokrylin, A.N. Dust storms in Turanian lowland. Proc. Russ. Acad. Sci. Geogr. Ser. 1996, 6, 48-54.

51. Aitsi-Selmi, A.; Egawa, S.; Sasaki, H.; Wannous, C.; Murray, V. The Sendai framework for disaster risk reduction: Renewing the global commitment to people's resilience, health, and well-being. Int. J. Disaster Risk Sci. 2015, 6, 164-176. [CrossRef] 
52. Guan, Q.; Sun, X.; Yang, J.; Pan, B.; Zhao, S.; Wang, L. Dust storms in northern China: Long-term spatiotemporal characteristics and climate controls. J. Clim. 2017, 30, 6683-6700. [CrossRef]

53. Orlovsky, L.; Orlovsky, N.; Durdyev, A. Dust storms in Turkmenistan. J. Arid Environ. 2005, 60, 83-97. [CrossRef]

54. Met Office. MIDAS: Global Weather Observation Data. In NCAS British Atmospheric Data Centre; 2006. Available online: https://catalogue.ceda.ac.uk/uuid/0ec59f09b3158829a059fe70b17de951 (accessed on 20 May 2020).

55. Xu, X.; Chen, H. Influence of vegetations and snow cover on sand-dust events in the west of China. Chin. Sci. Bull. 2006, 51, 331-340. [CrossRef]

56. Anyamba, A.; Tucker, C.J. Analysis of Sahelian vegetation dynamics using NOAA-AVHRR NDVI data from 1981-2003. J. Arid Environ. 2005, 63, 596-614. [CrossRef]

57. Funk, C.C.; Brown, M.E. Intra-seasonal NDVI change projections in semi-arid Africa. Remote Sens. Environ. 2006, 101, 249-256. [CrossRef]

58. Holm, A.M.R.; Cridland, S.W.; Roderick, M.L. The use of time-integrated NOAA NDVI data and rainfall to assess landscape degradation in the arid shrubland of Western Australia. Remote Sens. Environ. 2003, 85, 145-158. [CrossRef]

59. Tabari, H.; Aghajanloo, M.B. Temporal pattern of aridity index in Iran with considering precipitation and evapotranspiration trends. Int. J. Clim. 2013, 33, 396-409. [CrossRef]

60. de Martonne, E. Aréisme et Indice d'aridité. Comptes Rendus Acad. Sci. 1926, 2, 1395-1398.

61. Thornthwaite, C.W. An approach toward a rational classification of climate. J. Nucl. Mater. 1948, 66, 55-94. [CrossRef]

62. O'Loingsigh, T.; McTainsh, G.H.; Tews, E.K.; Strong, C.L.; Leys, J.F.; Shinkfield, P.; Tapper, N.J. The Dust Storm Index (DSI): A method for monitoring broadscale wind erosion using meteorological records. Aeolian Res. 2014, 12, 29-40. [CrossRef]

63. Cao, H.; Liu, J.; Wang, G.; Yang, G.; Luo, L. Identification of sand and dust storm source areas in Iran. J. Arid Land 2015, 7, 567-578. [CrossRef]

64. WMO. WMO code 4677 Present weather symbols. In Manual on Codes; WMO: Bremerhaven, Germany, 2011; p. 357.

65. Aili, A.; Oanh, N.T.K.; Abuduwaili, J. Variation Trends of Dust Storms in Relation to Meteorological Conditions and Anthropogenic Impacts in the Northeast Edge of the Taklimakan Desert, China. Open J. Air Pollut. 2016, 5, 127-143. [CrossRef]

66. Wang, Y.Q.; Zhang, X.Y.; Gong, S.L.; Zhou, C.H.; Hu, X.Q.; Liu, H.L.; Niu, T.; Yang, Y.Q. Surface observation of sand and dust storm in East Asia and its application in CUACE/Dust. Atmos. Chem. Phys. 2008, 8, 545-553. [CrossRef]

67. Breckle, S.-W. Aralkum: A Man-Made Desert: The Desiccated Floor of the Aral Sea (Central Asia), 1st ed.; Springer: Berlin, Germany, 2012; pp. 1-488.

68. Issanova, G.; Abuduwaili, J.; Kaldybayev, A.; Semenov, O.; Dedova, T. Dust storms in Kazakhstan: Frequency and division. J. Geol. Soc. India 2015, 85, 348-358. [CrossRef]

69. Shao, Y.; Dong, C.H. A review on East Asian dust storm climate, modelling, and monitoring. Glob. Planet Chang 2006, 52, 1-22. [CrossRef]

70. Tada, R.; Zheng, H.; Clift, P.D. Evolution and variability of the Asian monsoon and its potential linkage with uplift of the Himalaya and Tibetan Plateau. Prog. Earth Planet. Sci. 2016, 3, 4. [CrossRef]

71. Saura, J.R.; Reyes-Menendez, A.; Palos-Sanchez, P. Mapping multispectral Digital Images using a Cloud Computing software: Applications from UAV images. Heliyon 2019, 5, e01277. [CrossRef]

72. Palos-Sanchez, P.; Saura, J.R. The effect of internet searches on afforestation: The case of a green search engine. Forests 2018, 9, 51. [CrossRef] 
73. Yu, F.; Price, K.P.; Ellis, J.; Feddema, J.J.; Shi, P. Interannual variations of the grassland boundaries bordering the eastern edges of the Gobi Desert in central Asia. Int. J. Remote Sens. 2004, 25, 327-346. [CrossRef]

74. Zhang, Z.; Huisingh, D. Combating desertification in China: Monitoring, control, management, and revegetation. J. Clean. Prod. 2018, 182, 765-775. [CrossRef]

(C) 2020 by the authors. Licensee MDPI, Basel, Switzerland. This article is an open access article distributed under the terms and conditions of the Creative Commons Attribution (CC BY) license (http://creativecommons.org/licenses/by/4.0/). 